\title{
Pore-Size Controlled and Aminated Poly( $\gamma$-methyl L-glutamate) Particles for Selective Removal of Nucleic Acids
}

\author{
Chuichi Hirayama, ${ }^{\dagger}$ Masayo Sakata, Ken Moriguchi, Hiroshi Mizokami, \\ Hirotaka IHARA, and Kunio OHKuma* \\ Department of Applied Chemistry \& Biochemistry, Faculty of Engineering, Kumamoto University, \\ 2-39-1 Kurokami, Kumamoto 860-8555, Japan \\ *The Chemo-Sero-Therapeutic Research Institute, Shimizu, Kumamoto 860-8568, Japan
}

(Received October 20, 1997)

\begin{abstract}
This report describes a method for selective removal of nucleic acids from various protein solutions, using aminated poly $\left(\gamma\right.$-methyl L-glutamate) (PMLG- $\left.\mathrm{NH}_{2}\right)$ particles. The adsorbing activity for nucleic acids (purified DNA from salmon spermary) increased with increase in either the amino-group content or pore-size (molecular mass exclusion of polysaccharide, $M_{\mathrm{lim}}$ ) of the particles. The apparent dissociation constant between the DNA and the particles (amino-group content: 3.5 meq $\mathrm{g}^{-1}$ ) decreased from $8.2 \times 10^{-13} \mathrm{moll} \mathrm{l}^{-1}(\mathrm{M})$ to $2.0 \times 10^{-13} \mathrm{M}$ with increase in pore size from $2 \times 10^{3}$ to $2 \times 10^{5}$, at $\mathrm{pH} 7.0$ and an ionic strength of $\mu=0.05$. On the other hand, the adsorbing activity of bovine serum albumin increased with increasing $M_{\text {lim }}$ of the particles, but decreased with increasing ionic strength of the buffer. As a result, when $M_{\text {lim }}$ was $2 \times 10^{3}$ and amino-group content was $3.5 \mathrm{meqg}^{-1}$, PMLG-NH $\mathrm{NH}_{2}$ particles removed DNA from various DNA-containing samples, such as protein solutions, at $\mathrm{pH} 7.0$ and ionic strength $(\mu)$ of 0.2 . The particles also removed DNA from crude antigen solutions originating from Bordetella bronchiseptica and Pasteurella multocida. A high recovery of protective antigen $(100 \%)$ was obtained with each sample solution after removal of the DNA, and the concentration of DNA in it decreased to below $10 \mathrm{ng} \mathrm{ml}^{-1}$.
\end{abstract}

KEY WORDS Nucleic Acid / Deoxyribonucleic Acid / Aminated Poly( $\gamma$-methyl L-glutamate) Particle / Selective Removal / Pore Size / Amino-Group Content / Bovine Serum Albumin /

In the field of recombinant DNA technology, removal of DNA from crude drug materials is very important, because of the apprehension of the nonspecific pathophysiological reactions in mammals by injection of the fluid including recombinant DNA. ${ }^{1}$ The methods of the sucrose density gradient centrifugation ${ }^{2,3}$ and gel filtration $^{4,5}$ have been used in attempts to purify the antigen in crude antigen solution from cell extract. However, these methods are no efficient and practical way of removing DNA from a solution that contains high-molecular-weight substances such as antigens.

For removal of nucleic acids from solutions of cell products, such as proteins, adsorption method has proved to be most effective. Recently, some adsorbents for nucleic acids, chitosan particles ${ }^{6}$ and histidine-immobilized Sepharose, ${ }^{7,8}$ have become commercially available. Although these adsorbents have high capacities of adsorbing DNA, adsorption of such acidic protein as bovine serum albumin (BSA) is also caused at a low ionic strength of $\mu=0.02$ and a neutral $\mathrm{pH}$ value. As the ionic strength increased, the adsorption of BSA by the adsorbents decreased, but this was accompanied by a decrease in the adsorption of DNA. ${ }^{8}$

We attempted, therefore, to develop new adsorbents which are capable of retaining a high selectivity for nucleic acids in solutions of high-molecular weight compounds over a wide range of ionic strength. We previously reported that aminated poly $(\gamma$-methyl Lglutamate) (PMLG) particles, which have diaminoethane as a ligand, have a high adsorbing activity of endotoxin (a pyrogenic lipopolysaccharide; LPS) ${ }^{9,10}$ LPS is an amphipathic substance having both anionic (phosphoric acid groups) and hydrophobic regions (lipophilic

\footnotetext{
$\dagger$ To whom correspondence should be addressed.
}

groups). ${ }^{11}$ Nucleic acids are also high-molecular weight substances with phosphoric acid groups. ${ }^{12}$ Therefore, we considered that aminated PMLG particles may be used as selective adsorbents for nucleic acids.

In this paper we consider first the effects of aminogroup content and pore size of the adsorbent on the adsorption of purified DNA or various other cell products by PMLG-NH$H_{2}$ particles. We then describe the method of eliminating DNA from various protein solutions using PMLG- $\mathrm{NH}_{2}$ particles.

\section{EXPERIMENTAL}

\section{Materials}

PMLG was kindly supplied by Ajinomoto Co., Inc., Tokyo. Diaminoethane was purchased from Nacalai Tesque, Kyoto. The purified nucleic acids (DNA from salmon spermary $\left(M_{w}: 3 \times 10^{5}\right)$, DNA from calf thymus $\left(M_{w}: 1.5 \times 10^{5}\right)$, DNA from human placenta $\left(M_{w}\right.$ : $\left.1 \times 10^{5}\right)$, RNA from yeast $\left.\left(M_{w}: 2.5 \times 10^{5}\right)\right)$ were purchased from Wako Pure Chemical Ind. Ltd., Osaka.

Ovalmin (from eggs, $M_{w}: 4.5 \times 10^{4}, \mathrm{p} I$ : 4.6 ), albumin (from bovine serum, $M_{w}: 6.9 \times 10^{4}, \mathrm{p} I: 4.9$ ), insulin (from bovin pancreas, $M_{w}: 3.6 \times 10^{4}, \mathrm{p} I: 5.3$ ), fibrinogen (from human plasma, $M_{w}: 3.4 \times 10^{5}, \mathrm{p} I: 5.5$ ), Myoglobin (from horse heart, $M_{w}: 1.8 \times 10^{4}, \mathrm{p} I: 6.8$ ),$\gamma$-globulin (from human serum, $\left.M_{w}: 1.6 \times 10^{5}, \mathrm{p} I: 7.4\right)$, cytochrome C (from horse heart, $M_{w}: 1.3 \times 10^{4}, \mathrm{pI}: 10.6$ ) were purchased from Sigma Chemical Co., Ltd.

The cell extracts of $B$. bronchiseptica strain S1 and $P$. multocida strain 70 were provided by Chemo-Sero Therapeutic Research Institute. The cell extracts were prepared by sonication, centifugation and filtration $\left(0.45 \mu \mathrm{m}\right.$ Milipore filter) as described previously. ${ }^{4,5}$

The fluorescent dye 4',6-diamidino-2-phenylindole 
dihydrochloride hydrate ${ }^{13}$ for fluorometric analysis was purchased from Nacalai Tesque. Chitosan particles (Kurimuver II) were purchased from Kurita Water Industries Ltd., Tokyo and used as a standard adsorbent. DEAE-Cellulofine (Chisso Co., Ltd., Tokyo), DEAESepharose CL-6B (Pharmacia Biotech, Sweden), and Diaion-WA-30 (Mitsubishi Chemical Co., Ltd., Tokyo) were also used as adsorbents. All other chemicals were of analytical reagent grade.

\section{Preparation of PMLG-NH $\mathrm{H}_{2}$ Adsorbent}

PMLG- $\mathrm{NH}_{2}$ particles were prepared by suspension evaporation $^{14.15}$ following aminolysis ${ }^{9}$ (with diaminoethane) as described. The amino-group content of the adsorbent was adjusted by controlling the reaction conditions of temperature, time and the ratio of diaminoethane to the spheres. The PMLG-NH 2 particles obtained were washed successively with water, hot water, methanol and ethanol. PMLG- $\mathrm{NH}_{2}$ particles with diameters of 44 to $105 \mu \mathrm{m}$, with amino-group content of $<0.1$ to $3.5 \mathrm{meqg}^{-1}$, and with pore size $\left(M_{\mathrm{lim}}\right.$ as molecular mass of polysaccharide) of $2 \times 10^{3}$ to $2 \times 10^{5}$ were used as adsorbents.

\section{Determination of Amino-Group Contents, $M_{\mathrm{lim}}$, and Porosity of Adsorbent}

The amino groups were quantified by $\mathrm{pH}$ titration and elemental analysis as previously described. ${ }^{9}$ The pore size $\left(M_{\text {lim }}\right)$ of the matrix in the adsorbent was estimated from the calibration curves by aqueous size exclusion chromatography as described. ${ }^{10,16}$ Homogeneous series of pullulan and maltose were used as permeable substances. $M_{\text {lim }}$ values of adsorbent were reduced as the molecular mass of polysaccharide. ${ }^{10}$

\section{Adsorption of Nucleic Acids or Other Substances}

Nucleic acids (DNA or RNA) were dissolved in the

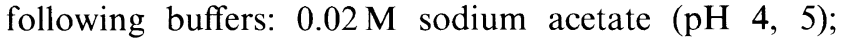
$0.02 \mathrm{M}$ phosphate $(\mathrm{pH} 6,7,8) ; 0.02 \mathrm{M}$ Tris $(\mathrm{pH} \mathrm{9,10).}$ The ionic strength of the buffer was adjusted by changing the content of sodium chloride. The adsorption of nucleic acids was measured by a batchwise method as follows: the adsorbent was washed and equilibrated with various buffers with different $\mathrm{pH}$ and ionic strengths. A 0.1 - to $0.4-\mathrm{g}$ portion of wet adsorbent was suspended in $2-4 \mathrm{ml}$ of a DNA or RNA solution. The suspension was shaken for $2 \mathrm{~h}$ at $25^{\circ} \mathrm{C}$ and filtered through a Millipore filter $(0.8 \mu \mathrm{m})$ to remove the adsorbent. The DNA or RNA content of the filtrate was determined.

The apparent dissociation constant $\left(K_{\mathrm{d}}\right)$ between DNA and adsorbent was estimated by adsorption isotherm as previously described. ${ }^{8}$

The adsorption of cell products other than DNA was investigated by a method similar to DNA-binding assay.

\section{DNA and Protein Assay}

The DNA or RNA concentration in the sample solution was determined by a fluorometric analysis with a Spectrofluorophotometer RF-540 (Shimadzu) using the fluorescent dye 4',6-diamidino-2-phenylindole dihydrochloride hydrate. ${ }^{17}$ The protein concentration was measured at $280 \mathrm{~nm}$ with a Spectrophotometer UV-160 (Shimadzu).
Table I. Adsorption of DNA by various adsorbents.

\begin{tabular}{|c|c|c|c|c|}
\hline \multicolumn{4}{|c|}{ Adsorbent } & \multirow{2}{*}{$\begin{array}{l}\text { Adsorp- } \\
\text { tion of } \\
\text { DNA }^{c}\end{array}$} \\
\hline \multirow{2}{*}{ Name } & $\begin{array}{l}\text { Amino-group } \\
\text { content }\end{array}$ & \multirow{2}{*}{$M_{\mathrm{lim}}^{\mathrm{a}}$} & Porosity $^{b}$ & \\
\hline & meq $g^{-1}$-adsorbent & & $\%$ & $\%$ \\
\hline PMLC-1 & $<0.1$ & $2 \times 10^{3}$ & 58 & 5 \\
\hline PMLG-1-NH ${ }_{2}-1.7$ & 1.7 & $2 \times 10^{3}$ & 65 & 46 \\
\hline PMLG-1-NH $2-3.5$ & 3.5 & $2 \times 10^{3}$ & 68 & 82 \\
\hline PMLG-2 & $<0.1$ & $1 \times 10^{4}$ & 67 & 8 \\
\hline PMLG-2-NH ${ }_{2}-1.7$ & 1.7 & $1 \times 10^{4}$ & 68 & 66 \\
\hline PMLG-2-NH $2-3.5$ & 3.5 & $1 \times 10^{4}$ & 70 & 89 \\
\hline PMLG-3 & $<0.1$ & $5 \times 10^{4}$ & 70 & 22 \\
\hline PMLG-3-NH -1.7 & 1.7 & $5 \times 10^{4}$ & 72 & 95 \\
\hline PMLG-3-NH $2-3.5$ & 3.5 & $5 \times 10^{4}$ & 74 & 99 \\
\hline PMLG-4-NH ${ }_{2}-3.5$ & 3.5 & $1 \times 10^{5}$ & 79 & 99 \\
\hline PMLG-5-NH -3.5 & 3.5 & $2 \times 10^{5}$ & 81 & 99 \\
\hline Chitosan particles & 3.8 & $>2 \times 10^{6}$ & - & 99 \\
\hline DEAE-Cellulofine & 0.03 & $7 \times 10^{3}$ & 67 & 23 \\
\hline $\begin{array}{l}\text { DEAE-Sepharose } \\
\text { CL-6B }\end{array}$ & 0.15 & $3 \times 10^{4}$ & 62 & 64 \\
\hline Diaion WA30 & 4.3 & $4 \times 10^{3}$ & 43 & 16 \\
\hline
\end{tabular}

${ }^{a}$ Amino-groups introduced in to the adsorbent. ${ }^{b}$ Calculated by calibration curves of SEC in aqueous solution. ${ }^{\mathrm{c}}$ The adsorption of DNA was determined by a batchwise method with $0.4 \mathrm{~g}$ of wet adsorbent and $4 \mathrm{ml}$ of a DNA solution (DNA from salmon spermary: $500 \mu \mathrm{g} \mathrm{ml}^{-1}$, $\mathrm{pH} 7.0, \mu=0.05$ ).

\section{Antigen Assay}

The concentration of antigens (dermonectrotic toxins (DNT)) in sonic extracts of $B$. bronchiseptica and $P$. multocida were determined in guinea pig as described previously. ${ }^{4}$ The antigen concentration was expressed in one toxic unit (TU) $\mathrm{ml}^{-1}$ of DNT. TU was defined as the highest dilution inducing a necrotic lesion of $\geq 5 \mathrm{~mm}$ in diameter. The total content of protein in the sonic extract was measured by the method of Lowry et al. ${ }^{18}$

\section{RESULTS AND DISCUSSION}

\section{Effects of Amino-Group Content and Pore Size on DNA-Adsorbing Activity}

The DNA-adsorbing activities of the adsorbents were examined by a batchwise method with various kinds of buffers. The purified DNA (from salmon spermary) was used as a standard DNA sample.

Table I shows the DNA-adsorbing activities of various adsorbents (amino-group content of $<0.1$ to $4.3 \mathrm{meq}$ $\mathrm{g}^{-1}, M_{\text {lim }}$ of $2 \times 10^{3}$ to $>2 \times 10^{6}$ ) at $\mathrm{pH} 7.0$ and ionic strength $\mu=0.05$. The various PMLG-NH $\mathrm{N}_{2}$ particles, Chitosan particles, DEAE-Cellulofine, DEAE-Sepharose CL-6B, and Diaion-WA-30 were used as adsorbents. The adsorbing activity for DNA increased with increase in either the amino-group content or pore-size $\left(M_{\text {lim }}\right)$ of PMLG-NH ${ }_{2}$. PMLG-NH $\mathrm{N}_{2}$ with large pore size (aminogroup content: $3.5 \mathrm{meq} \mathrm{g}^{-1}, M_{1 \mathrm{im}}: 5 \times 10^{4}-2 \times 10^{5}$ ) showed excellent adsorbing activity (99\%) of DNA. The commercially available DNA adsorbent, chitosan particles, also showed high adsorbing activity (99\%). In contrast, DEAE-Cellulofine, DEAE-Sepharose CL6B, and Diaion-WA-30, which have been widely used as ion exchangers, were unsatisfactory with respect to adsorbing activity (16-64\%).

When removing DNA from a solution by adsorp- 
Table II. DNA-adsorption capacity and apparent dissociation constant between adsorbent and DNA

\begin{tabular}{|c|c|c|c|c|}
\hline \multicolumn{3}{|c|}{ Adsorbent } & \multirow{3}{*}{$\begin{array}{c}\text { Adsorption capacity } \\
\text { of DNA } \\
\mathrm{mgg}^{-1} \text {-adsorbent }\end{array}$} & \multirow{3}{*}{$\frac{K_{\mathrm{d}, \mathrm{app}}}{\mathrm{moll}^{-1}}$} \\
\hline \multirow{2}{*}{ Name } & Amino-group content & \multirow{2}{*}{$M_{\mathrm{lim}}$} & & \\
\hline & meq $\mathrm{g}^{-1}$-adsorbent & & & \\
\hline PMLG-1-NH ${ }_{2}-1.7$ & 1.7 & $2 \times 10^{3}$ & 4.0 & $8.5 \times 10^{-12}$ \\
\hline PMLG-1-NH -3.5 & 3.5 & $2 \times 10^{3}$ & 6.5 & $8.2 \times 10^{-13}$ \\
\hline PMLG-5-NH $\mathrm{N}_{2}-3.5$ & 3.5 & $2 \times 10^{5}$ & 14.2 & $2.0 \times 10^{-13}$ \\
\hline Chitosan particles & 3.8 & $>2 \times 10^{6}$ & 15.0 & $7.9 \times 10^{-13}$ \\
\hline
\end{tabular}

The DNA-adsorption capacity per $\mathrm{g}$ adsorbent and the apparent dissociation constant $\left(K_{\mathrm{d}, \mathrm{app}}\right)$ of DNA to adsorbent were estimated by adsorption isotherm, as described previously. ${ }^{5}$ The adsorption isotherm of DNA was determined by a batchwise method with $0.1 \mathrm{~g}$ of wet adsorbent and $4 \mathrm{ml}$ of a DNA solution (DNA from salmon spermary $\left(M_{w}: 3 \times 10^{5}\right): 1$ to $10^{5} \mu \mathrm{g} \mathrm{ml}^{-1}, \mathrm{pH} 7.0, \mu=0.05$ ). The $K_{\text {dapp }}$ was expressed in moll ${ }^{-1}$ of molecular weight of DNA.

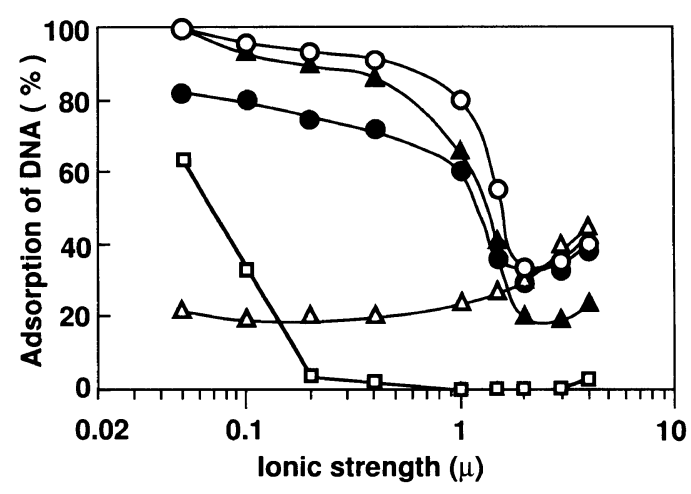

Figure 1. Effects of ionic strength on adsorption of DNA by various adsorbents. The adsorption of DNA was determined by a batchwise method with $0.2 \mathrm{~g}$ of the wet adsorbent and $2 \mathrm{ml}$ of a DNA solution (DNA purified from salmon spermary: $500 \mu \mathrm{g} \mathrm{ml}^{-1}, \mathrm{pH}$ of the buffer: 7.0). Adsorbent, pore size $\left(M_{\mathrm{lim}}\right)$, and amino-group content $\left(\mathrm{meq} \mathrm{g}^{-1}\right)$ : $\mathrm{O}=$ PMLG-5-NH $-3.5,2 \times 10^{5}, 3.5 ; \bigcirc=$ PMLG-1-NH $-3.5,2 \times 10^{3}$, 3.5; $\triangle=$ PMLG-5, $2 \times 10^{5},<0.1 ; \mathbf{\Delta}=$ chitosan particles (Kurimuber II), $>2 \times 10^{6}, 3.8 ; \square=$ DEAE-Sepharose CL-6B, $3 \times 10^{4}, 0.15$.

tion, it is necessary to check not only the adsorption capacity but also dissociation constant $\left(K_{\mathrm{d}}\right)$ between the DNA and adsorbent. The adsorption capacities and the apparent dissociation constants $\left(K_{\mathrm{d} \text {,app }}\right)$ are estimated based on adsorption isotherms as previously described. ${ }^{5}$ The results are shown in Table II. The adsorption isotherms of DNA for PMLG- $\mathrm{NH}_{2}$ (amino-group content: 3.5 or $1.7 \mathrm{meq} \mathrm{g}^{-1}, M_{\mathrm{lim}}: 2 \times 10^{3}$ or $2 \times 10^{5}$ ) and the chitosan particles were determined by a batchwise method in a phosphate buffer ( $\mathrm{pH} 7.0, \mu=0.05)$ by changing the concentration of DNA. The DNA-adsorbing capacity increased with an increase in the aminogroup content and the pore-size. Although the chitosan particles, which have the largest pore size $\left(M_{\mathrm{lim}}\right.$ : over $\left.2 \times 10^{6}\right)$ and amino-group content $\left(3.8\right.$ meq $\left.^{-1}\right)$, showed the largest DNA-adsorption capacity, the PMLG-5$\mathrm{NH}_{2}-3.5$ had the smallest $K_{\mathrm{d} \text {,app }}$ value $\left(2.0 \times 10^{-13} \mathrm{M}\right.$ as molecular weight $\left(3 \times 10^{5}\right)$ of DNA). The smaller the $K_{\text {d,app }}$ values of the adsorbent, the higher its removing activity. These results indicate that the DNA-removing activities of the PMLG- $\mathrm{NH}_{2}$ adsorbents $\left(M_{\mathrm{lim}}\right.$ of $2 \times$ $10^{3}$ to $2 \times 10^{5}$, amino-group content of $3.5 \mathrm{meq}^{-1}$ ) are higher than that of the chitosan particles when the removal of DNA from a dilute DNA solution is attempted.

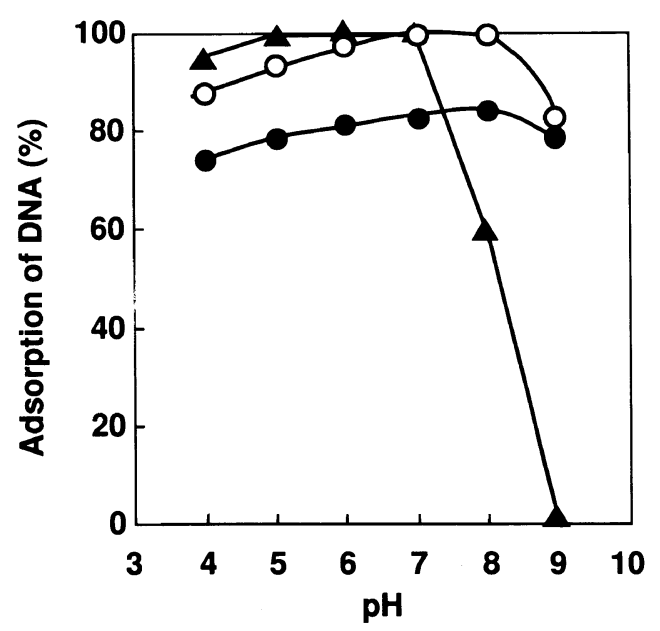

Figure 2. Effect of $\mathrm{pH}$ on adsorption of DNA by PMLG-5-NH $\mathrm{N}_{2}-3.5$

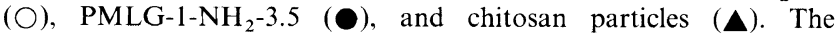
adsorption of DNA was determined by a batchwise method with $0.2 \mathrm{~g}$ of the wet adsorbent and $2 \mathrm{ml}$ of a DNA solution (DNA from salmon spermary: $500 \mu \mathrm{g} \mathrm{ml}^{-1}$, ionic strength of the buffer: $\mu=0.05$ ).

\section{Effects of Ionic Strength and $\mathrm{pH}$ on DNA-Adsorbing Activity}

The effects of ionic strength on DNA adsorption by various adsorbents were examined in phosphate buffer (pH 7.0, $\mu=0.05$ to 4.0 ), and the results are shown in Figure 1. When the ionic strength was increased $(\mu=0.05$ to 2.0), the DNA-adsorbing activity of the all aminated adsorbents decreased. However, when the ionic strength was higher than 2.0, DNA-adsorbing activity of these adsorbents increased only slightly. By contrast, the adsorption of DNA to PMLG-5 (non-aminated) particles increased from 22 to $45 \%$ with increasing ionic strength from $\mu=0.05$ to 4.0 . The PMLG-5- $\mathrm{NH}_{2}-3.5$ particles showed the highest DNA-adsorbing activity (99 to $35 \%$ ) at $\mu=0.05$ to 2.0 . Chitosan particles also had a high DNA-adsorbing activity (99 to 20\%) under these conditions. The adsorbing activity of DEAE-Sepharose CL-6B decreased markedly when the ionic strength was increased to $\mu=0.1$ or higher.

The effect of $\mathrm{pH}$ on DNA adsorption by PMLG-5$\mathrm{NH}_{2}-3.5$ and PMLG-1-NH $\mathrm{NH}_{2}-3.5$ particles was compared with that of the chitosan particles. As shown in Figure 2, each PMLG- $\mathrm{NH}_{2}$ adsorbent showed a high DNAadsorbing activity $(75-99 \%)$ at a wide $\mathrm{pH}$ range from 4 to 9 . Higher DNA-adsorbing activity was observed in the PMLG-5- $\mathrm{NH}_{2}-3.5$ with the larger pore size. On the 
other hand, chitosan particles showed high adsorption for DNA only at $\mathrm{pH} 4$ to 7.

From these results (Figures 1 and 2) we assumed that the adsorbing-activity of the PMLG- $\mathrm{NH}_{2}$ for DNA was due to the simultaneous effects of cationic properties which originated from ligands and hydrophobic or other properties which originated from the matrix. We have previously reported that the PMLG particles show an inherent tendency towards hydrophobicity, ${ }^{19}$ and the adsorbing-activity of PMLG particles for LPS resulted from their hydrophobic properties. ${ }^{9,10}$ The introduction of amino groups into the PMLG particles induced an ionic interaction between LPS and the adsorbent. ${ }^{9}$

On the other hand, Nucleic acids (DNA and RNA) are polynucleosides having anionic regions (phosphate groups), pentoses, purine bases, and pyrimidines. ${ }^{12}$ Their adsorbing activity, being dependent on the ionic strength and $\mathrm{pH}$ values of the buffer, suggests a cationic interaction. DEAE-Sepharose CL-6B adsorbs DNA mainly by cationic interaction, adsorbing less DNA at high ionic strength values $(\mu=0.2-4.0$ and $\mathrm{pH} 7.0)$ (Figure 1). The adsorbing activity of the PMLG-NH and the chitosan particles were also dependent on ionic strength and $\mathrm{pH}$ values. As shown in Figure 2, the DNA was bound more strongly by PMLG-NH $\mathrm{NH}_{2}$ than by chitosan particles at a high $\mathrm{pH}$ ( 8 and 9 ). This difference is attributable to the fact that the $\mathrm{p} K_{\mathrm{a}}$ of the aminated PMLG particles ( $K_{\mathrm{a}}: 7.9$ to 8.2 ) is higher than that of the chitosan particles $\left(\mathrm{p} K_{\mathrm{a}}: 6.2\right)$. Since the useful $\mathrm{pH}$ range for DNA adsorption increased with increase in the $\mathrm{p} K_{\mathrm{a}}$ of the adsorbent.

Furthermore, non-aminated PMLG can adsorb DNA over a wide range of ionic strengths $(\mu=0.05-4.0)$, and non-aminated and aminated PMLG particles showed similar adsorption of DNA ( 35 to $45 \%$ ) at a high ionic strength of $\mu=4.0$ (Figure 1). Matsumae et al. ${ }^{8}$ reported that a hydrophobic bound was formed between cell product (endotoxin, DNA, RNA) and histidineimmobilized Sepharose under the condition of high ionic strength $(\mu>3)$. These results suggest that nonaminated and aminated PMLG particles adsorb DNA by hydrophobic effects which originate from the matrix.

\section{Adsorption Behavior for Various Cell Products}

It is important to check adsorbing activity for cell products (with the exception of nucleic acids) in order to examine selective removal of DNA. Figure 3 shows the effect of $M_{\text {lim }}$ on adsorption of DNA, BSA, and $\gamma$-globulin by the PMLG-NH $\mathrm{NH}_{2}$ particles at an ionic strength of $\mu=0.17$ and $\mathrm{pH} \mathrm{7.2,} \mathrm{which} \mathrm{is} \mathrm{equivalent} \mathrm{to}$ that of physiological saline. The adsorption rates of all cell products increased with increasing $M_{\text {lim }}$ of the adsorbent from $2 \times 10^{3}$ to $2 \times 10^{5}$. Only when the PMLG-NH $\mathrm{N}_{2}$ with $M_{1 \mathrm{im}}$ of $2 \times 10^{3}$ and amino-group content of $3.5 \mathrm{meq} \mathrm{g}^{-1}$ (PMLG-1-NH $\mathrm{NH}_{2}-3.5$ ) was used as the adsorbent, was the DNA adsorbed without adsorption of BSA and $\gamma$-globulin.

Figures $4 \mathrm{a}$ and $\mathrm{b}$ show the effect of ionic strength of the buffer on the adsorption of BSA and $\gamma$-globulin. The adsorption of each protein increased with increase in the $M_{\text {lim }}$ of the PMLG-NH $\mathrm{N}_{2}$ particles. Although the PMLG-5-NH $-3.5\left(M_{1 \mathrm{im}}: 2 \times 10^{5}\right)$ adsorbed BSA (97 to $8 \%$ ) (Figure $4 \mathrm{a}$ ) and $\gamma$-globulin (8 to $9 \%$ ) (Figure $4 \mathrm{~b}$ ) at

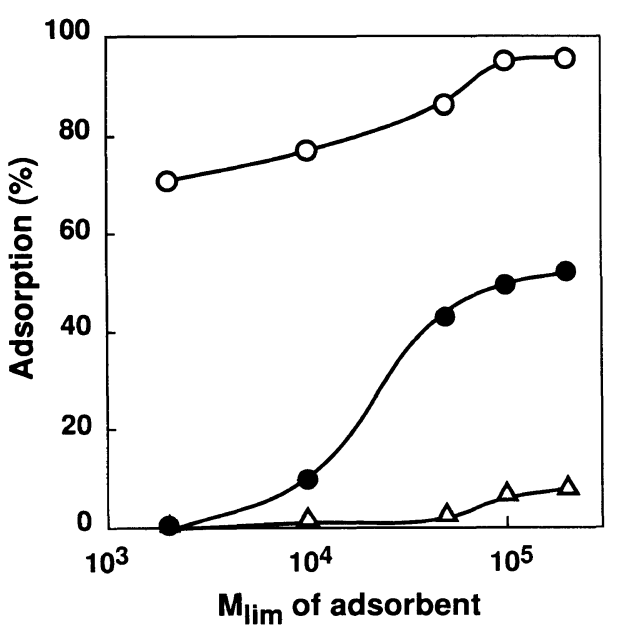

Figure 3. Effect of $M_{\text {lim }}$ on adsorption of DNA (O), BSA (O), and $\gamma$-globulin $(\triangle)$ by PMLG- $\mathrm{NH}_{2}$ adsorbents $\left(M_{\text {lim }} 2 \times 10^{3}-2 \times 10^{5}\right.$, amino-group content $3.5 \mathrm{meq} \mathrm{g}^{-1}$ ). The adsorption of a cell product was determined by a batchwise method with $0.4 \mathrm{~g}$ of the wet adsorbent and $4 \mathrm{ml}$ of a cell product solution (sample: $500 \mu \mathrm{g} \mathrm{ml}^{-1}, \mathrm{pH} 7.2$, $\mu=0.17$ ). $M_{w}$ of cell product: DNA (salmon spermary) $=3 \times 10^{5}$; $\mathrm{BSA}=6.9 \times 10^{4} ; \gamma$-globulin $=1.6 \times 10^{5}$.
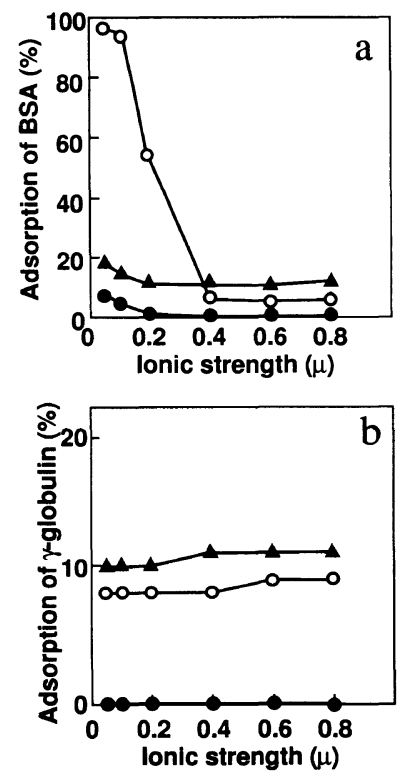

Figure 4. Effects of ionic strength on adsorption of BSA (a) and $\gamma$-globulin (b) by various adsorbents. The adsorption of a protein was determined by a batchwise method with $0.4 \mathrm{~g}$ of the wet adsorbent and $4 \mathrm{ml}$ of a protein solution (sample: $500 \mu \mathrm{g} \mathrm{ml}^{-1}$, pH of the buffer: 7.0 ). Adsorbent, pore size $\left(M_{\mathrm{lim}}\right)$, and amino-group content $\left(\mathrm{meqg}^{-1}\right)$ : $\mathrm{O}=$ PMLG-5-NH $-3.5,2 \times 10^{5}, 3.5 ; 0=$ PMLG-1-NH $-3.5,2 \times 10^{3}$, 3.5; $\mathbf{\Delta}=$ chitosan particles, $>2 \times 10^{6}, 3.8$.

an ionic strength of $\mu=0.05$ to 0.8 , the PMLG-1-NH -3.5 $\left(M_{1 \mathrm{im}}: 2 \times 10^{3}\right)$ adsorbed little protein (below $\left.1 \%\right)$ under these conditions. These results (Figures $4 \mathrm{a}$ and $\mathrm{b}$ ) showed that adsorption of protein caused mainly by entry of the protein into the pores of the adsorbent. This indicates that both BSA $\left(M_{w}: 6.9 \times 10^{4}\right)$ and $\gamma$-globulin $\left(M_{w}\right.$ : $\left.1.6 \times 10^{5}\right)$ can penetrate readily into the particle with $M_{\text {lim }}$ of $2 \times 10^{5}$, but can not penetrate into the particle with $M_{\lim }$ of $2 \times 10^{3}$.

Much of the standard DNA (from salmon spermary, $M_{w}: 3 \times 10^{5}$ ), however, was well adsorbed even by PMLG-1-NH -3.5 (less than the molecular mass of DNA), as shown in Figures 1, 2, and 3. The standard 
Table III. Adsorption of cell product by PMLG-1-NH $\mathrm{N}_{2}-3.5$

\begin{tabular}{|c|c|c|c|c|c|}
\hline \multirow{2}{*}{ Cell product } & \multirow{2}{*}{$\mathrm{p} I$} & \multicolumn{4}{|c|}{ Adsorption $/ \%$} \\
\hline & & $\mu=0.05$ & $\mu=0.2$ & $\mu=0.4$ & $\mu=0.6$ \\
\hline Ovalbumin & 4.6 & 25 & 0 & 0 & 0 \\
\hline BSA & 4.9 & 38 & 3 & 0 & 0 \\
\hline Insulin & 5.3 & 5 & 1 & 0 & 0 \\
\hline Fibrinogen & 5.5 & 25 & 2 & 0 & 0 \\
\hline Myoglobin & 6.8 & 0 & 0 & 0 & 0 \\
\hline$\gamma$-Globulin & 7.4 & 0 & 0 & 0 & 0 \\
\hline Cytochrome $c$ & 10.6 & 0 & 0 & 0 & 0 \\
\hline DNA (Salmon spermary) & & 99 & 98 & 90 & 82 \\
\hline DNA (Calf thymus) & & 99 & 99 & 93 & 93 \\
\hline DNA (Human placenta) & & 99 & 98 & 90 & 91 \\
\hline RNA (Yeast) & & 99 & 98 & 88 & 85 \\
\hline
\end{tabular}

a The adsorption of a cell product was determined by a batchwise method with $0.4 \mathrm{~g}$ of wet adsorbent $\left(-\mathrm{NH}_{2}: 3.5 \mathrm{meq} \mathrm{g}^{-1}, M_{\text {lim }}: 2 \times 10^{3}\right.$ ) and $4 \mathrm{ml}$ of a sample solution $\left(100 \mu \mathrm{g} \mathrm{ml}^{-1}, \mathrm{pH} \mathrm{7.0)}\right.$.

DNA cannot enter the pores of PMLG-1-NH $\mathrm{NH}_{2}-3.5$. Therefore, we assume that the standard DNA is adsorbed on the surface of the adsorbent.

It seems that the adsorption of the protein is induced by both cationic and hydrophobic properties. Matsumae et al. ${ }^{8}$ reported that acidic or neutral substances are adsorbed to histidine-immobilized Sepharose at a $\mathrm{pH}$ more basic than the isoelectric point of the substance under the condition of $\mu=0.02$. Aminated PMLG adsorbents has the same characteristics. The charge of BSA is anionic at $\mathrm{pH}$ values greater than its $\mathrm{pI}$ (4.9), and also the adsorption of BSA by the adsorbents is dependent on the ionic strength, as shown in Figure 4a. This suggests ionic interaction between the adsorbent and BSA. On the other hand, $\gamma$-globulin ( $I:$ : 7.4) is a neutral (pI: 7.4) and weakly hydrophobic protein, and its adsorption is independent of ionic strength, as shown in Figure $4 \mathrm{~b}$. These findings suggest the participation of hydrophobic binding.

The chitosan particles with large pore size $\left(M_{\text {lim }}\right.$ over $\left.2 \times 10^{6}\right)$ also adsorbed BSA $(11-19 \%)$ (Figure $\left.4 a\right)$ and $\gamma$-globulin $(10-12 \%)$ (Figure $4 b)$ in similar conditions. Only at an ionic strength of $\mu=0.05$ to 0.2 , is the BSA-adsorbing activities of PMLG- $\mathrm{NH}_{2}-5-3.5$ higher than that of the chitosan particles although the pore size of the PMLG- $\mathrm{NH}_{2}$ is smaller than that of the chitosan particles. This higher BSA-adsorbing activity is attributable to the fact that the $\mathrm{p} K_{\mathrm{a}}$ of PMLG-NH $\mathrm{H}_{2}$ is higher than that of the chitosan particles, as shown in Figure 2.

Table III shows the adsorption activities of the various cell products by PMLG-1-NH $-\mathrm{NH}_{2}-3.5$. Myoglobin, $\gamma$-globulin (neutral proteins), and cytochrome $c$ (a basic protein) were hardly adsorbed at any ionic strength value. Acidic substances were well adsorbed at $\mathrm{pH} 7.0$ and $\mu=0.05$. When the ionic strength was increased $(\mu=0.2)$, most acidic substances (with the exception of DNA and RNA) were scarcely adsorbed $(<3 \%)$. It is suggested that the binding force of the adsorbent to the nucleic acids is stronger than that to the protein ( $\mathrm{p} I$ : 4.6-10.6), because the nucleic acids have a lower $\mathrm{p} K_{\mathrm{a}}$ than the protein.

These results (Figures 3, 4, and Table III) suggest that PMLG-NH$-1-3.5$ can adsorb DNA without affecting the protein recovery and also that proper selec-
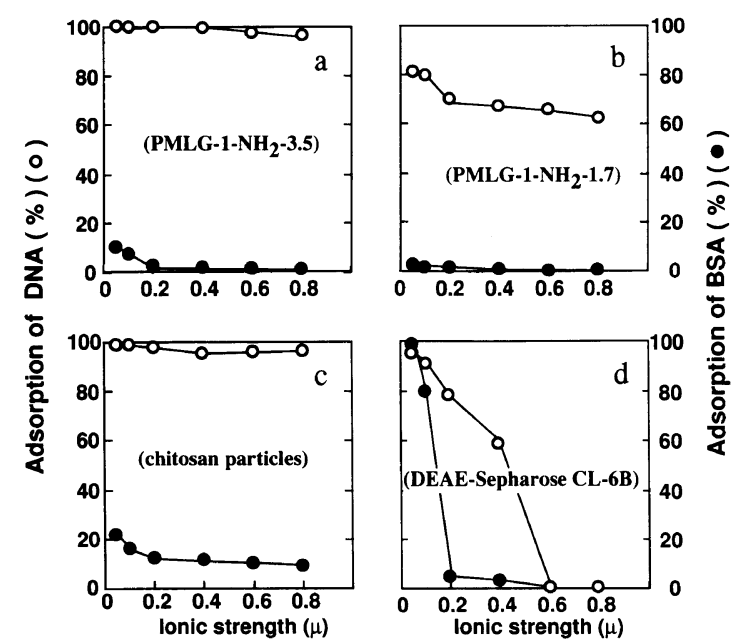

Figure 5. Effect of ionic strength on removal of DNA from a BSA solution containing DNA (BSA: $500 \mu \mathrm{g} \mathrm{ml}^{-1}$, DNA from salmon spermary: $10 \mu \mathrm{g} \mathrm{ml}^{-1}, \mathrm{pH} 7.0$ ) by various adsorbents. The removal of DNA was determined by a batchwise method with $0.4 \mathrm{~g}$ of the wet adsorbent and $4 \mathrm{ml}$ of a sample solution.

Table IV. Removal of DNA from various protein solutions containing DNA by PMLG-1-NH $\mathrm{N}_{2}-3.5$

\begin{tabular}{|c|c|c|c|}
\hline \multicolumn{2}{|l|}{ Protein $(\mathrm{p} I)$} & $\begin{array}{c}\begin{array}{c}\text { Removal of } \\
\text { DNA }\end{array} \\
\%\end{array}$ & $\begin{array}{c}\begin{array}{c}\text { Recovery of } \\
\text { protein }\end{array} \\
\% \%\end{array}$ \\
\hline Ovoalbumin & $(4.6)$ & 98.6 & 96 \\
\hline BSA & $(4.9)$ & 99.4 & 98 \\
\hline Fibrinogen & $(5.5)$ & 99.9 & 97 \\
\hline$\gamma$-Globulin & $(7.4)$ & 99.9 & 97 \\
\hline Cytochrome $c$ & $(10.6)$ & 99.9 & 99 \\
\hline
\end{tabular}

The removal of DNA was determined by a batchwise method with $0.4 \mathrm{~g}$ of the wet adsorbent (amino-group content: $3.5 \mathrm{meq} \mathrm{g}^{-1}, M_{\text {lim }}$ : $2 \times 10^{3}$ ) and $4 \mathrm{ml}$ of a sample solution (DNA from salmon spermary: $10 \mu \mathrm{g} \mathrm{ml}^{-1}$, protein: $500 \mu \mathrm{g} \mathrm{ml}^{-1}$, $\left.\mathrm{pH} 7.0, \mu=0.2\right)$.

tion for adjusting ionic strength and $\mathrm{pH}$ in buffer solutions enables selective removal of DNA and RNA from protein containing solutions.

\section{Selective Removal of DNA from Protein-Containing Solutions}

The effects of ionic strength on the selective removal of DNA from a BSA-containing solution with various adsorbents were examined (Figures 5a, b, c, and d). As shown in Figure 5a, PMLG-1- $\mathrm{NH}_{2}-3.5$ selectively removed DNA from a BSA solution at $\mu=0.2$ to 0.4 . PMLG-1-NH $\mathrm{N}_{2}-1.7$ had relatively poor DNA-adsorbing activity $(81-62 \%)$ at all ionic strength values although its recovery of BSA was high $(<98 \%)$ (Figure $4 \mathrm{~b})$. The chitosan particles showed adsorbing activities for both DNA $(95-99 \%)$ and BSA $(9-23 \%)$ at $\mu=0.05$ to 0.8 (Figure 4c). DEAE-Sepharose CL-6B had high adsorbing activities for both at low ionic strength, $\mu=0.05$, and the adsorbing activities decreased with increase in ionic strength (Figure 4d). The chitosan particle and DEAE-Sepharose CL-6B therefore could not selectively remove DNA from a BSA-DNA solution at any ionic strengths.

Table IV shows the selective removal of DNA from various useful protein solutions containing DNA 
Table V. Removal of DNA from antigen solutions originating from bacteria by PMLG-1- $\mathrm{NH}_{2}-3.5$

\begin{tabular}{|c|c|c|c|c|c|c|}
\hline \multicolumn{3}{|c|}{ Sample solution } & \multirow{2}{*}{\multicolumn{2}{|c|}{ Concentration of $\mathrm{DNA}^{\mathrm{c}} / \mathrm{ng} \mathrm{ml}^{-1}$}} & \multirow{2}{*}{\multicolumn{2}{|c|}{$\begin{array}{l}\text { Recovery of compound } \\
\text { after treatment } / \%\end{array}$}} \\
\hline \multirow[b]{2}{*}{ Substance } & \multirow{2}{*}{$\frac{\text { Protein }^{\mathbf{a}}}{\mathrm{mg} \mathrm{ml}^{-1}}$} & \multirow{2}{*}{$\frac{\mathrm{DNT}^{\mathrm{b}}}{\mathrm{TUml}^{-1}}$} & & & & \\
\hline & & & Before treatment & After treatment & Protein & DNT \\
\hline B. bronchiseptica sonicated extract & 9.8 & $2.5 \times 10^{4}$ & $6.5 \times 10^{5}$ & $<10$ & 94 & 100 \\
\hline P. multocida sonicated extract & 6.7 & $2.0 \times 10^{4}$ & $5.7 \times 10^{5}$ & $<10$ & 92 & 100 \\
\hline
\end{tabular}

The removal of DNA was determined by a batchwise method with $0.3 \mathrm{ml}(0.75 \mathrm{~g})$ of the adsorbent and $10 \mathrm{ml}$ of a sample solution in $0.02 \mathrm{M}$ phosphate buffer (pH 7.2, $\mu=0.17$ ). Assay methods: ${ }^{\mathrm{a}}$ The method of Lowry et al. ${ }^{\mathrm{b}}$ DNT assay. $\quad{ }^{\mathrm{c}}$ Fluorometric analysis.

(protein: $500 \mu \mathrm{g} \mathrm{ml}^{-1}$, the standard DNA: $10 \mu \mathrm{g} \mathrm{ml}^{-1}$ ) by PMLG-1- $\mathrm{NH}_{2}-3.5$. When the DNA adsorption was measured at $\mathrm{pH} 7.0$ and $\mu=0.2$, a high recovery of protein $(96-99 \%)$ was obtained with each sample solution after removal of DNA. The concentration of DNA in each sample solution decreased from 10 to below $0.1 \mu \mathrm{g} \mathrm{ml}^{-1}$.

Selective removal of DNA from crude antigen solutions from B. bronchiseptica and P. multocida was examined with PMLG-1- $\mathrm{NH}_{2}-3.5$ particles at an ionic strength $\mu=0.17$ and $\mathrm{pH} 7.2$. The results are shown in Table V. The particles were able to remove DNA from each crude antigen solution to a level below $10 \mathrm{ng} \mathrm{ml}^{-1}$ without loss of the antigen activity.

It is essential to eliminate DNA to be at least a concentration of $10 \mathrm{pg} \mathrm{ml}^{-1}$ from drugs produced by recombinant DNA technology. ${ }^{1}$ In this report, it was impossible to check if the DNA concentration of a sample solution after treatment was decreased to below $10 \mathrm{pg} \mathrm{ml}^{-1}$ because of the unsatisfactory sensitivity of DNA assay. However, the results (Tables IV and V) indicate that aminated PMLG particles can remove DNA from a drug to a level below $10 \mathrm{pg} \mathrm{ml}^{-1}$ without loss of proteins.

\section{CONCLUSIONS}

The present results suggest that the adsorption technique, which uses the aminated PMLG particles, can remove DNA from drugs and fluids for injection. This process did not affect the recovery of important compounds such as antigen. The high DNA selectivity of the particles is due to (1) the simultaneous effects of cationic properties of ligands and hydrophobic or other properties of matrix, (2) the exempting effects on protein molecules when the $M_{\text {lim }}$ rate is adjusted to $2 \times 10^{3}$, and (3) a higher $\mathrm{p} K_{\mathrm{a}}(8.2)$ than for Chitosan particles $\left(\mathrm{p} K_{\mathrm{a}}\right.$ : 6.0).
Acknowledgments. We are grateful to Dr. Y. Miyachi of Ajinomoto Co., Ltd. for providing the PMLG F-8000. This work was supported in part by a Grant-in-Aid for Scientific Research from the Ministry of Education, Science, and Culture of Japan.

\section{REFERENCES}

1. Point to consider in the production and testing of new drug and biologicals produced by recombinant DNA technology, Food and Drug Administration, U.S.A., 1985, p 12.

2. Y. Sato, J. L. Cowell, H. Sato, D. G. Burstyn, and C. R. Manclark, Infect. Immun., 41, 313 (1983).

3. A. Imaizumi, Y. Suzuki, A. Ginnaga, S. Sakuma, and Y. Sato, J. Microbiol. Methods, 2, 339 (1984).

4. K. Kume, T. Nakai, and Y. Samejima, and C. Sugimoto, Infect. Immun., 52, 370 (1986).

5. M. Endoh, M. Amitani, and Y. Nakase, Microbiol. Immunol., 30, 659 (1986).

6. C. Hirayama, H. Ihara, and J. Ida, Eur. Patent, 0345017.

7. S. Minobe, T. Watanabe, T. Sato, and I. Chibata, J. Chromatogr., 248, 401 (1982).

8. H. Matsumae, S. Minobe, K. Kindan, T. Watanabe, T. Sato, and T. Tosa, Biotechnol. Appl. Biochem., 12, 129 (1990).

9. C. Hirayama, H. Ihara, and X. Li, J. Chromatogr. Biomed. Appl., 530, $148(1990)$.

10. C. Hirayama, M. Sakata, Y. Ohkura, H. Ihara, and K. Ohkuma, Chem. Pharm. Bull., 40, 2106 (1992).

11. O. Westphal, O. Luderitz, C. Galanos H. Mayer, and E. T. Eietschel, Adv. Immunopharmacol., 3, 13 (1986).

12. S. Nishimura, Prog. Natl. Acad. Mol. Biol., 12, 49 (1972).

13. O. Dann, G. Bergen, T. Demant, and G. Volz, Ann. Chem., 794, 68 (1971).

14. H. Ihara, T. Yoshinaga, and C. Hirayama, J. Chromatogr., 362, 197 (1986).

15. C. Hirayama, H. Ihara, S. Nagaoka, H. Furusawa, and S. Tsuruta, Polym. J., 22, 614 (1990).

16. K. A. Granath and P. Flodin, Makromol. Chem., 48, 160 (1961).

17. F. B. Clifford, C. J. Kenneth, and W. J. Tomas, Anal. Bull., 40, $2106(1992)$.

18. O. H. Lowry, N. J. Rosebrough, A. L. Farr, and R. J. Randall, J. Biol. Chem., 193, 265 (1951).

19. Y. Motozato, H. Ihara, M. Nakamura, M. Shiba, and C. Hirayama, Nippon Kagaku Kaishi, 61 (1988). 